\title{
In Light of Democracy and Corruption: Institutional Determinants of Electricity Provision
}

\author{
Frida Boräng, ${ }^{a}$ Sverker C. Jagers, ${ }^{b}$ Marina Povitkina ${ }^{c}$
}

\begin{abstract}
Long-lasting democratic institutions have been found to matter for the universal provision of reliable electricity. In this article we revisit this finding, suggesting that the effect of democracy on electricity provision is moderated by the quality of institutions shaping the implementation of public policies. We test the hypothesis positing the interaction effect between democracy and corruption using cross-national data on the share of population living in unlit areas. The results show that democracy is associated with a higher electrification rate only in low-corrupt contexts. When corruption is widespread, democratic experience is not correlated with higher rates of electrification. These findings suggest that the effect of democratic institutions is conditional on the quality of the institutions that shape policy implementation.
\end{abstract}

Keywords: Democracy, Corruption, Electricity Provision, Political Institutions, Public administration

https://doi.org/10.5547/01956574.42.2.fbor

\section{INTRODUCTION}

Electricity is essential to social and economic development. For example, it has been described as the "lifeblood of the modern economy" (Min, 2015, 2), as most of the economic activities that we see in the world today are dependent upon a steady supply of electricity and a stable system to distribute it. Hence, access to affordable, reliable, and sustainable energy for all has been adopted as number seven of the United Nations" "Sustainable Development Goals" (SDG) (United Nations, 2015a). However, despite its importance for both economic and social activities, and the high and steady demand, there are few incentives for the private sector to contribute to the realization of universal electricity access. Since the private sector will not sufficiently value the positive economic externalities of electrification, electricity is an example of a type of good, such as merit goods or public goods, that could remain underprovided, if solely left to the private sector (Abbott, 2001; Samuelson, 1954), and thus requires public financing. ${ }^{1}$ Moreover, the building of large-scale

1. Electrification can be both rivalrous and excludable and, in this sense, is not a pure public good. Nevertheless, due to the fact that electrification will be underprovided by the private market (Min, 2015) and is often shaped by political factors (Baskaran, Min, and Uppal, 2015), the literature on the provision of public goods and services from political science is also relevant to understand electrification.

a Corresponding author. Department of Political Science, University of Gothenburg, 40530 Gothenburg, Sweden. E-mail: frida.borang@pol.gu.se.

b Department of Political Science, University of Gothenburg, 40530 Gothenburg, Sweden.

c Department of Political Science, University of Oslo, 0317, Oslo, Norway; Department of Political Science, University of Gothenburg, 40530 Gothenburg, Sweden.

The Energy Journal, Vol. 42, No. 2. This is an open access article under the terms of the Creative Commons Attribution License (CC-BY), which permits use, distribution and reproduction in any medium, provided the original work is properly cited. All rights reserved. 
transmission and distribution infrastructure (both key electricity assets) is both expensive and needs investments over a long time, which is usually of little interest to commercial investors. Hence, the fulfilment of SDG 7, i.e. providing electricity to entire populations, is — and will remain — primarily politically driven (Baskaran, Min, and Uppal, 2015).

One of the central questions in research on the drivers behind the successful provision of public services is what role political institutions play in it. More specifically, does it matter whether a country's political regime is democratic or autocratic? A large strand of previous research argues that democratic regimes are more favorable to public service provision than authoritarianism, because when political leaders are held accountable to the citizens in fair and regular elections, it creates strong incentives among political leaders to deliver broadly demanded public services, including affordable and reliable electricity (Acemoglu and Robinson, 2006; Sen, 1999). However, there are also several reasons why democratic institutions may fail to produce and provide enough public services needed to satisfy the demand of the majority of voters. For example, clientelism may distort political attention away from the general provision of the electricity assets toward the interests of narrower groups (Hicken, 2011; Kitschelt, 2000). Similarly, elected leaders often work with short time horizons (Haggard, 1991; Keefer, 2007), whereas more general provision of goods and services - not least in the form of investments in electrical power infrastructure - is a much longer-term undertaking than governments' regular terms of office.

Research on the effects of political systems and institutions on energy provision, has often been hampered by a lack of adequate and reliable data. A novel approach is used by Brian Min in his prominent book "Power and the Vote" (2015). By using satellite imagery of night-time lights, together with data on population in specific areas, Min estimates the effect of democratic history on the share of countries' populations that live in lit areas. Using this objective data, Min (2015) finds that countries with longer democratic experience have a higher proportion of people living in lit areas, implying higher electrification rates.

While the years a country has been democratic are no doubt important for whether it can deliver to its citizens, the age of democracy does not sufficiently capture the processes within political systems that may favor or hamper the universal public service delivery. We argue that in order to gain a more nuanced understanding of how political institutions impact the provision of various societal goods and services, we have to take into account not only factors that shape political incentives to provide such services, but also pay attention to the institutions aimed at generating them. We thus theorize that although there are strong reasons to expect that democratic rules provide politicians with strong incentives to deliver public services - in this case electricity - to citizens, their actual ability to provide such goods is dependent on the access to reasonably well-functioning administrative apparatus. This leads us to estimate the effect of democracy on electricity access conditional on the level of corruption in the public administration.

The rest of the paper is organized in the following way. First, we describe why democracy is expected to positively affect electricity provision. Thereafter, we theorize how this relationship may be moderated by the presence of corruption. This is followed by a presentation of data and methodology. Finally, we present our results, followed by a discussion and some concluding remarks.

\section{POLITICAL INSTITUTIONS AND LARGE-SCALE ELECTRIFICATION}

\subsection{Democracy and the provision of societal goods and services - the case of electricity}

Electrification provides access to the benefits of electricity to wide segments of the population. Since there are few incentives for individuals or the private sector to contribute to the real- 
ization of universal electricity access, private markets are unlikely to meet this goal. While some private investments in electrification have occurred in specific areas, particularly in large cities, electrification in places with a dispersed settlement and/or low population density, such as rural areas, can and has seldom been motivated by economic calculations. For these reasons, private electric utilities have historically been reluctant to extend electricity services to rural areas. Instead, most countries achieved rural electrification through special national programs and funding arrangements, including the use of subsidies (Zomers, 2003). Hence, undertaking electricity provision to an entire population is primarily politically driven, implying that political institutions play an important role. They determine patterns of electricity provision through the building of infrastructure, subsidies, price regulation, and other regulatory structures (Brown and Mobarak, 2009; Min, 2015).

One of the central questions in research on the drivers behind the provision of societal goods and services is to what degree and how political regimes and institutions affect it. Democratic institutions are generally believed to favor the provision of public services (Acemoglu and Robinson, 2006; Sen, 1999; Bueno de Mesquita, 2003; Gandhi and Przeworski, 2006; Lake and Baum, 2001; McGuire and Olson, 1996). While governments in authoritarian or semi-authoritarian states also face pressure to provide benefits such as electricity, they normally need support from narrower interest groups than democratically elected leaders typically do. There are strong theoretical expectations that democracy will benefit the interests of the median voter rather than the economic elites (Meltzer and Richard, 1981). In the context of electrification, attention to the interests of the median voter in many cases would imply bringing electricity to rural areas - something that, as argued above, is unlikely to happen without political will.

Indeed, some empirical studies show that electricity provision matters for citizens' evaluations of political leaders in democracies (for example see Chhibber, Shastri, and Sisson, 2004), which in turn affects political leaders' campaign strategies (Baskaran, Min, and Uppal, 2015). Brown and Mobarak (2009) also find that democratization leads to more electricity use, at least among the poorer countries. Similarly, Ahlborg et al. (2015) link the level of democracy to household electricity consumption in African countries.

Simultaneously, there are a number of reasons why democratization may not result in electricity provision passable enough to satisfy the voters' demand, e.g., due to politicians focusing on re-election rather than generating general welfare to the voters (Besley and Coate, 1998). In addition, elected leaders often work with short time horizons (Haggard, 1991; Keefer, 2007) whereas provision of societal goods and services - not least in the form of investments in electric power infrastructure - is a long-term undertaking (Min, 2015). Moreover, clientelism and vote buying (i.e. exchange of goods and services for political support) tend to distort the political attention toward the interests of narrower groups (Bratton and Van de Walle, 1994; Bratton and Van de Walle, 1997; Chandra, 2004; Kitschelt, 2000; Hicken, 2011). Furthermore, the empirical evidence for a positive correlation between democracy and public services has also been mixed (Ross, 2006).

Rather than the level of democracy at a particular point of time, some studies instead assert that it is the accumulated experience with democracy that should matter for democracies' performance in providing societal goods and services, since the effects of democracy should accumulate and unfold over a significant amount of time (Gerring, Thacker, and Alfaro, 2012; Min, 2015). An important study using this approach is that of Min (2015), where he, using the novel and precise satellite imagery data of night-time lights, documents a significant positive impact of democratic experience on the share of population living in lit areas.

While the literature on democratic accountability and public service provision, including the key study by Min (2015), adds to our understanding of how political decisions are shaped by 
democratic institutions, we believe we need to take into account the ability of leaders to deliver on their decisions in order to understand the success of large-scale electrification projects. In other words, the focus on accountability and incentive structures for political leaders tends to overlook situations where political leaders wish to provide societal goods and services (because they have strong electoral incentives for it) but are simply not able to do so (Ahlborg et al., 2015). ${ }^{2}$

\subsection{Public sector corruption and the provision of societal goods and services}

This paper argues that to further our understanding of the processes through which a highlevel political decision to increase electrification rates results or does not result in actual electrification, we must partly shift our focus from democratic procedures towards the functioning of the implementation apparatus within polities - the output side of the political processes. This is because the ability of political leaders to actually provide public services is dependent on the access to reasonably well-functioning administrative institutions that effectively and (cost) efficiently implement the stipulated policies. One key characteristic of the administration is the level of corruption, conventionally defined as the abuse of public power for private gain (Mauro, 1998; Gupta, Davoodi, and Tiongson, 2000; Holmberg, Rothstein, and Nasiritousi, 2009; Kaufmann and Kraay, 2002; Nye, 1967; North, 1990). Democracies are by no means free from corruption. On the contrary, public sector corruption is often ascribed as a part of 'bad governance', which is a 'specter haunting democracy in the world today' (Diamond, 2007).

Corruption can shape the effect of democratic rule on large-scale electrification in several ways. First, corruption can distort the positive link between policymaking and policy implementation, as the intended policies do not become properly implemented due to the 'vanished' resources. With the corrupt rules of the game, there are more incentives for incumbents and bureaucrats to appropriate funds coming from tax revenues or donors, which could have otherwise been assigned for the provision of public services, including electrification. In particular, the literature on rural electrification in developing countries has identified poor organizational structures and corruption as important barriers to successful electrification (for example, Ahlborg and Hammar, 2014; Jones and Thompson, 1996; Karekezi and Majoro, 2002).

Second, corruption intervenes in the process of recruitment to the public sector, facilitating favoritism and nepotism at the cost of meritocratic recruitment. Appointments by, e.g., family ties are often associated with less competence and professionalism in the public sector (Lewis, 2007; Dahlström and Lapuente, 2017). This has consequences for the provision of electricity, as electrification is a technically complicated task that requires specific expertise in order for it to be sufficiently implemented and maintained (Gormley and Balla, 2012).

Third, the presence of dysfunctional public administration can negatively affect the link between democratic rule and public service provision by influencing the policy choices of both decision-makers and citizens in democracies, including long-standing democracies (Rothstein, Samanni, and Teorell, 2012; Dahlström, Lindvall, and Rothstein, 2013). Thus, democratic rulers are presumably less likely to commit to large-scale electrification if they know that their bureaucracies are incapable of implementing the task.

Although the expectation that democratic rule secures more service provision is based on the assumption that citizens' demand for public services - and thus demand for public spending-

2. We would like to note that Min does discuss the ability of leaders to provide public goods $(2015: 30,96-7)$ and he includes state capacity as a control variable in his robustness tests. It is however not theorized or empirically investigated whether the quality of the implementing institutions moderates the relationship between democracy and electricity provision, which, we argue, is a relevant question. 
eventually translates into demands on politicians to provide such services, it is far from given that citizens will turn to the state for large-scale solutions to their problems (see, for example, Rothstein, Samanni, and Teorell, 2012). If citizens do not trust that public authorities are able to deliver public services, for example suspecting that tax money is lost to corruption, they may not be willing to take the risk of demanding higher public spending, which often implies higher taxes.

Thus, people's confidence in the implementing agencies is likely to matter for public service provision (Rothstein, 2011). Large-scale infrastructure projects - as well as many other public services - can be seen as 'high-risk projects' dependent on vertical trust to succeed. Low trust in implementing agencies can increase the likelihood of low-risk choices among voters and politicians; the result being private, targeted spending rather than spending on universal public service provision. On the contrary, a trustworthy public administration is likely to have a higher ability to provide public services, not least through its ability to build consent for the collection of taxes and other contributions. Finally, even when the private sector contributes to the electricity provision, the quality of the public sector is important, as it typically shapes the efficiency of public-private sector partnerships in service delivery (Dahlström, Nistotskaya, and Tyrberg, 2018).

There are case studies illustrating the adverse effects of corruption on electrification (for example, Ahlborg and Hammar, 2014; Beekman, Bulte, and Nillesen, 2014). However, to our knowledge, there are few studies that hypothesize the effect of democracy on electricity conditional on corruption, as illustrated in Figure 1 (Boräng, Jagers, and Povitkina, 2016). As a result, it is still uncertain whether the expected positive effect from being a democracy persists in the high-corrupt context or disappears.

Figure 1: Democracy, corruption and electrification

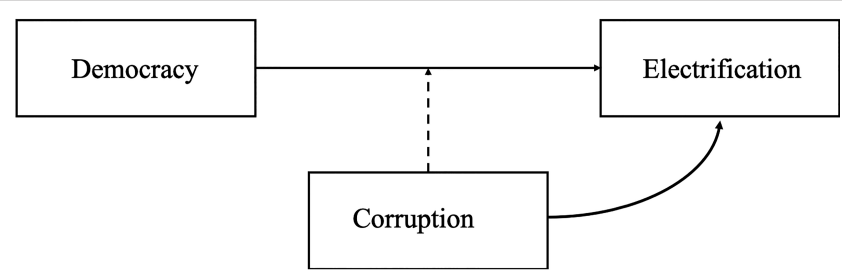

Based on these arguments, our expectation is that when the public sector is ridden with corruption, democracy will have a smaller, or even non-existent, effect on electricity provision. We thus hypothesize that:

$\mathrm{H}_{1}$ : The effect of democratic experience on electricity provision is conditional on the level of corruption in the public administration.

Previous studies investigating whether the success of public service provision in various political regimes depends on the capabilities of the public sector find that more democracy either compensates the absence of state capacity, e.g., in providing economic growth (Knutsen, 2013), healthcare, and education (Hanson, 2015), or complements it, e.g., in preparing for natural disasters (Ahlbom Persson, and Povitkina, 2017), mitigating climate change (Povitkina, 2018), and providing water quality (Povitkina and Bolkvadze, 2019). In our study we test if the previously found conditional effect of democracy also holds for the provision of large-scale electrification.

Our tests narrow down the broad notion of state capacity to the corruption in the public sector, as it captures the underlying mechanisms of the conditional effect of democracy more precisely. Moreover, our analysis offers a harder test than has been offered previously by incorporating democratic experience instead of the levels of democracy at a given point of time and at the same 
time making our results directly comparable with the established findings by Min (2015) in the area of electrification. Our study also provides an additional test to Min's important findings and offers a more nuanced understanding of the political determinants of electricity provision.

\section{DATA AND METHOD}

Our analysis follows the empirical strategy laid out by Min (2015) to ensure that our results are compatible for comparison. Our models are approximated to the models offered by Min to achieve accurate replication. After we replicate Min's findings, we proceed with our contribution. Our dependent variable is the percentage of the population living in unlit areas from Min (2015), based on satellite images from the Defense Meteorological Satellite Program's Operational Linescan System (DMSP-OLS). High-resolution images, taken by satellite from an altitude of $830 \mathrm{~km}$ each night between 20:00 and 21:30 local time, capture the concentration of outdoor lights around the globe. The data are smoothened to reflect only stable lights, excluding short-term events such as fires and lightning. The indicator ranges from 0 to 100, where higher numbers imply a greater population living in the unlit areas. For a more detailed description on the calculation of the measure, see Min (2015). The data of the dependent variable are taken for the year 2003 and this is for two reasons. First, it makes our results comparable with the findings by Min (2015). Second, and more importantly, analyzing the association between political factors and electrification as a proxy for public service provision earlier in time provides a more informative test of the relationship, because there was a greater margin for further electrification in 2003 than nowadays, when more people are connected to the grid.

Min's (2015) data, based on the satellite images of night-time lights in combination with population grids, offers a number of advantages over the alternative measures of electrification. It is objective and its accuracy does not depend on country-specific political and economic factors. Compared to data on access rates and electricity consumption, it avoids the problems of incorrect or inconsistent reporting. One of the main critiques of using night-time-light satellite data for measuring electrification is that it is not possible to distinguish the source of the electricity provider, which can be both public and private. As previous research argues that most electricity provision tends to be arranged by the governments (Lal, 2005), our expectation is that the share of private providers will be small and is therefore likely to create additional noise in the data rather than affect the results in any substantial way. In addition, we expect that the success of service provision by the private sector will also depend on political factors, as the previous literature suggests (see Dahström, Nistotskaya, and Tyrberg, 2018). Another disadvantage with using satellite data is that it is problematic for over-time comparisons due to uneven sensitivity of satellites' sensors between years. Therefore, our analysis is bound to exploring differences between countries rather than developments within countries over time.

The parts of our analysis, which replicate the results by Min (2015) use similar independent variables from the same data sources where possible. We gauge democracy with the dichotomous measure provided by Cheibub, Gandhi, and Vreeland (2010) and similarly construct a measure of democratic experience, capturing the number of years over the period 1946-2002 that a country has been coded as democracy. Using experience with democracy rather than levels of democracy at a given point of time allows capturing the mechanisms described in the theory section.

While there is always a risk of endogeneity problems in studies linking political institutions and public service provision, the fact that we use a measure which cumulates over such a long period of time before the dependent variable is measured, mitigates the problem in this case. Moreover, our models also control for a natural logarithm of a country's gross domestic product (GDP) per capita 
to account for the level of industrialization in a country and the availability of financial resources for building the grid lines necessary to transmit electricity. The measure of GDP per capita is taken from Gleditsch (2011). We control for population density, as it is easier to provide access to a densely living population, and for the percentage of the rural population in a country, as it is more difficult to provide access to rural areas. Both indicators are taken from the World Development Indicators (2014). To account for the relationship between ethnic diversity and public service provision, the analysis includes the measure of ethno-linguistic fractionalization, taken from Fearon and Laitin (2003). Similarly to Min (2015), we control for a country's landscape using a measure for mountainous terrain from Fearon and Laitin (2003), as mountains make the building of electricity infrastructure more costly; and a measure of a country's latitude, to account for the difference in the hours of darkness per year across the globe. Our measure of latitude comes from La Porta et al. (1999) and is available through Teorell et al. (2018). ${ }^{3}$ We use the measure of oil production in metric tons per capita with data from Ross and Mahdavi (2015) to account for gas flares captured in the dependent variable and for countries' access to non-renewable electricity sources. We also include the number of civil armed conflicts a country has been through during the period 1946-2002 and multiply it by the number of years a country has been in each conflict to capture the accumulated damage that conflicts can bring. ${ }^{4}$ Ongoing conflicts may disrupt electricity supply, while previous conflicts could have contributed to the destruction of grids. The data are taken from the PRIO Armed Conflict Dataset (Themnér and Wallensteen, 2013). While the measure differs from the one used by Min (2015), it nevertheless captures the essence of Min's variable and comes from the same data source. Data for all independent variables are obtained from the Quality of Government Institute (QoG) database (Teorell et al., 2018). All independent variables are taken for the year 2002, one year prior to the year when our dependent variable is measured. As a result, the replicated models have 148 cases.

Our second main independent variable - corruption in public administration, which we introduce after replicating the results by Min (2015) - is taken from the Varieties of Democracy dataset (Coppedge et al., 2018a). The indicator measures to what extent employees in the public sector engage in corrupt exchanges, that is provide favors for bribes, and the extent to which they "steal, embezzle, or misappropriate public funds or other state resources for personal or family use." The indicator ranges from 0 to 1 where higher values mean higher corruption. For more information about the indicator, including the questions incorporated into the aggregation of the index, see Varieties of Democracy project codebook (Coppedge et al., 2018b). The models with the corruption variable included have 147 cases. Serbia and Montenegro drop out from the model due to a different data aggregation technique used in the construction of the Varieties of Democracy dataset. For the list of all countries included in the models, see Appendix B.

To model the moderating effect of corruption and check if the effect of democracy is different at different levels of corruption, we multiply corruption with the democracy variable and include both the interaction term and the constituent parts of it into the same equation. Summary statistics for all variables used in the study and correlations between them are presented in Appendix A. ${ }^{5}$

To test the hypotheses, our analysis uses fractional logistic regression suggested by Papke and Wooldridge (1996) and Wooldridge (2002, 661) and used by Min (2015) to estimate the relationship between democracy experience and the proportion of the population living in unlit areas.

3. The missing values on latitude are collected from atlas data.

4. We do not use the measure used by Min (2015) in his study as it is difficult to construct it given the current data structure of the PRIO dataset.

5. While correlation between some of the variables is relatively high, the VIF tests showed that there is no multicollinearity in our models, implying that high correlation between the variables is not a problem for our empirical tests. 
This estimation is useful because, in contrast with OLS regression, it forces the predicted values to fall inside the $0-1$ interval, which is defined by the variance range of the dependent variable. In fractional logit, the predicted values on the dependent variable are generated by the following logistic function:

$$
E(y \mid z)=\frac{\exp (Z)}{1+\exp (Z)}
$$

where $y$ is the dependent variable and $Z$ is defined by the function:

$$
Z=\beta_{0}+\beta_{1} d+\beta_{2} c+\beta_{3} d c+\beta_{k} x
$$

where $d$ is democracy, $c$ is corruption, $d c$ is an interaction term Democracy*Corruption and $x$ is a vector of control variables. The partial effects from Equation 1 are roughly comparable to the coefficients from the OLS regression. All models are run with Huber-White robust standard errors to correct for heteroscedasticity.

\section{RESULTS}

Table 1 presents the results. Models 1 and 2 replicate Min's (2015) models and show the relationship between democratic experience and the proportion of the population living in unlit areas (note that Min's tables show the proportion living in lit areas). The direction of the relationship and

Table 1: Relationship between democratic experience, public sector corruption and the share

\begin{tabular}{|c|c|c|c|c|c|}
\hline $\begin{array}{l}\text { DV: share of population } \\
\text { living in unlit areas }\end{array}$ & $\begin{array}{c}\text { Model } \\
1\end{array}$ & $\begin{array}{c}\text { Model } \\
2\end{array}$ & $\begin{array}{c}\text { Model } \\
3\end{array}$ & $\begin{array}{c}\text { Model } \\
4\end{array}$ & $\begin{array}{l}\text { Model } \\
5\end{array}$ \\
\hline Democracy experience & $\begin{array}{c}-0.038^{* * *} \\
(0.005)\end{array}$ & $\begin{array}{c}-0.016^{* *} \\
(0.005)\end{array}$ & $\begin{array}{c}-0.025 * * * \\
(0.007)\end{array}$ & $\begin{array}{c}-0.017 * * * \\
(0.005)\end{array}$ & $\begin{array}{c}-0.029 * * * \\
(0.008)\end{array}$ \\
\hline Public sector corruption & & & $\begin{array}{c}1.532 * * \\
(0.468)\end{array}$ & $\begin{array}{l}-0.105 \\
(0.329)\end{array}$ & $\begin{array}{l}-0.374 \\
(0.397)\end{array}$ \\
\hline Democracy*corruption & & & & & $\begin{array}{l}0.024 \dagger \\
(0.013)\end{array}$ \\
\hline GDP per capita $(\ln )$ & & $\begin{array}{c}-0.363^{* *} \\
(0.121)\end{array}$ & & $\begin{array}{c}-0.373 * * \\
(0.135)\end{array}$ & $\begin{array}{c}-0.368^{* *} \\
(0.136)\end{array}$ \\
\hline Latitude & & $\begin{array}{c}-0.025 * * * \\
(0.007)\end{array}$ & & $\begin{array}{c}-0.025^{* * *} \\
(0.007)\end{array}$ & $\begin{array}{c}-0.023^{* *} \\
(0.007)\end{array}$ \\
\hline Population density (ln) & & $\begin{array}{c}-0.158^{* *} \\
(0.051)\end{array}$ & & $\begin{array}{c}-0.157 * * \\
(0.051)\end{array}$ & $\begin{array}{c}-0.160 * * \\
(0.051)\end{array}$ \\
\hline Mountainous terrain $(\ln )$ & & $\begin{array}{c}0.033 \\
(0.048)\end{array}$ & & $\begin{array}{c}0.034 \\
(0.047)\end{array}$ & $\begin{array}{c}0.027 \\
(0.046)\end{array}$ \\
\hline Ethnic fractionalization & & $\begin{array}{c}-0.418 \\
(0.341)\end{array}$ & & $\begin{array}{c}-0.411 \\
(0.345)\end{array}$ & $\begin{array}{l}-0.410 \\
(0.343)\end{array}$ \\
\hline Rural population (per cent) & & $\begin{array}{c}0.023 * * * \\
(0.006)\end{array}$ & & $\begin{array}{c}0.023 * * * \\
(0.006)\end{array}$ & $\begin{array}{c}0.023 * * * \\
(0.006)\end{array}$ \\
\hline Conflicts & & $\begin{array}{c}0.005 * * * \\
(0.001)\end{array}$ & & $\begin{array}{c}0.006 * * * \\
(0.001)\end{array}$ & $\begin{array}{c}0.005^{* * * *} \\
(0.001)\end{array}$ \\
\hline Oil production per capita & & $\begin{array}{c}-0.094^{*} \\
(0.044)\end{array}$ & & $\begin{array}{c}-0.092 * \\
(0.044)\end{array}$ & $\begin{array}{c}-0.089 * \\
(0.041)\end{array}$ \\
\hline Constant & $\begin{array}{c}-0.756^{* * *} \\
(0.122)\end{array}$ & $\begin{array}{l}1.966 \dagger \\
(1.158)\end{array}$ & $\begin{array}{c}-1.843 * * * \\
\quad(0.395)\end{array}$ & $\begin{array}{c}2.105 \\
(1.367)\end{array}$ & $\begin{array}{c}2.233 \\
(1.387)\end{array}$ \\
\hline Observations & 148 & 148 & 147 & 147 & 147 \\
\hline
\end{tabular}
of population living in unlit areas.

Robust standard errors in parentheses, $* * * \mathrm{p}<0.001 ; * * \mathrm{p}<0.01 ; * \mathrm{p}<0.05 ; \dagger \mathrm{p}<0.1$.

The measure of democratic experience in this table is based on the measure by Cheibub, Gandhi, and Vreeland (2010). $\mathrm{DV}=$ dependent variable; GDP = gross domestic product; $\mathrm{ln}$ = natural logarithm.

All independent variables are taken for the year 2002. Dependent variable is taken for the year 2003. 
size of the coefficients on all variables resemble the findings by Min, apart from the variable measuring the effect of conflicts on electrification, which is now positive and significant, implying that higher number of conflicts and longer duration of conflicts have a negative impact on electrification rates. The results similarly show that longer experience with democracy is associated with fewer people living without light. Model 3 introduces the variable measuring public sector corruption into the equation and shows that higher corruption is related to a higher share of the population living in unlit areas when controlling for the years of democratic history. The relationship disappears, however, when accounting for the rest of the factors identified as important predictors, as shown in Model 4. Model 5 provides a test for the interaction effect between democracy experience and the levels of corruption on electricity provision, as suggested by Hypothesis 1 . The significant interaction term in Model 5 implies that democracy's effect is indeed conditional on the level of corruption. To study the nature of the interaction, we calculate the predicted probabilities at each level of corruption and plot them.

The marginal effect plot in Figure 2 shows the contingent effect of democratic experience on every value of public sector corruption with 95 per cent confidence intervals based on Model 5 in Table 1. The graph illustrates that the effect of democratic experience on electrification rates is only significant when corruption levels are low. When corruption is higher than $0.7^{6}$ on the $0-1$ scale, which is the level of Moldova, the effect of democracy disappears and no longer seems to play a role in electrification rates. The overlaid frequency distribution of country-cases specifies that the

Figure 2: The relationship between democratic experience and the proportion of population living in unlit areas conditional on public sector corruption.

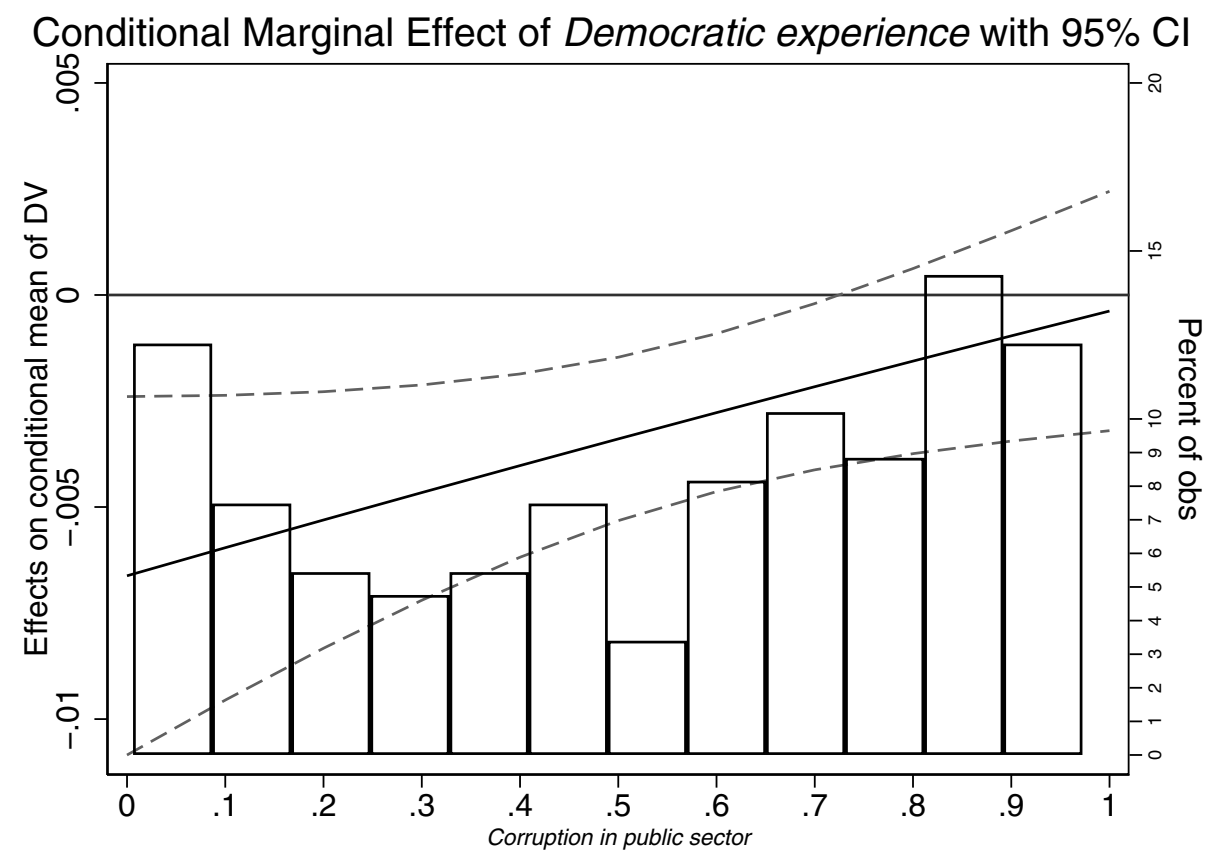

Note: $\mathrm{DV}=$ dependent variable; $\mathrm{CI}=$ confidence intervals

6. The threshold of 0.7 is taken from the calculation of marginal effects. According to the results, when corruption takes a value above this point, the effect of democracy on electricity provision becomes insignificant. 
effect of democratic experience on electricity provision is insignificant for about 37 per cent of the observations in the sample or, more specifically, 56 cases. By looking more closely at the data, we find that this sub-sample of corrupt countries includes both those countries that had no democratic experience throughout 1946-2002, such as Afghanistan, Russia or Zimbabwe, and countries that have up to 47 years of democratic history, such as Venezuela and Guatemala. This implies that the relationship holds not only for countries which experienced relatively few years of democracy, but also for those states that have been under a democratic rule for a long period of time relative to the rest of the sample, but which, at the same time, have not managed to develop a strong well-performing public administration. Summary statistics for the cases where the effect of democratic experience on electricity provision is significant and cases where democracy does not have a significant effect is provided in Table 2 .

Table 2: Summary statistics of democratic experience in sub-samples where the effect of democratic experience is significant and not significant

\begin{tabular}{lcccccc}
\hline & Obs & $\begin{array}{c}\text { Mean of democratic } \\
\text { experience }\end{array}$ & Std. Dev. & Min & Max & $\begin{array}{c}\text { Mean of } \\
\text { corruption }\end{array}$ \\
\hline $\begin{array}{l}\text { Sample where the effect of democratic } \\
\text { experience is not significant }\end{array}$ & 56 & 6.54 & 11.40 & 0 & 47 & 0.85 \\
$\begin{array}{l}\text { Sample where the effect of democratic } \\
\text { experience is significant }\end{array}$ & 92 & 23.60 & 21.65 & 0 & 58 & 0.34 \\
\hline
\end{tabular}

Note: Obs = observations, Std.Dev. $=$ standard deviation, Min = minimum value, Max = maximum value.

Table 3: Relationship between democratic experience, public sector corruption and the share of population living in unlit areas. Alternative specifications

\begin{tabular}{|c|c|c|c|}
\hline $\begin{array}{l}\text { DV: share of population living } \\
\text { in unlit areas }\end{array}$ & $\begin{array}{c}1 \\
\text { Excluding } \\
\text { OECD }\end{array}$ & $\begin{array}{c}2 \\
\text { Developing countries } \\
\text { GNI }<11905\end{array}$ & $\begin{array}{c}3 \\
\text { Freedom } \\
\text { House/PolityIV index }\end{array}$ \\
\hline Democracy experience & $\begin{array}{c}-0.037 * * * \\
(0.010)\end{array}$ & $\begin{array}{c}-0.034 * * \\
(0.011)\end{array}$ & $\begin{array}{l}-0.050 * * \\
(0.019)\end{array}$ \\
\hline Public sector corruption & $\begin{array}{l}-0.525 \\
(0.405)\end{array}$ & $\begin{array}{l}-0.519 \\
(0.411)\end{array}$ & $\begin{array}{l}-0.557 \\
(0.458)\end{array}$ \\
\hline Democracy*corruption & $\begin{array}{l}0.035^{*} \\
(0.016)\end{array}$ & $\begin{array}{l}0.033^{*} \\
(0.016)\end{array}$ & $\begin{array}{l}0.059^{*} \\
(0.028)\end{array}$ \\
\hline GDP per capita (ln) & $\begin{array}{c}-0.317^{*} \\
(0.134)\end{array}$ & $\begin{array}{c}-0.265^{*} \\
(0.124)\end{array}$ & $\begin{array}{c}-0.376^{* *} \\
(0.139)\end{array}$ \\
\hline Latitude & $\begin{array}{c}-0.024 * * \\
(0.007)\end{array}$ & $\begin{array}{c}-0.027 * * * \\
(0.007)\end{array}$ & $\begin{array}{c}-0.021 * * \\
(0.007)\end{array}$ \\
\hline Population density (ln) & $\begin{array}{c}-0.139 * * \\
(0.051)\end{array}$ & $\begin{array}{l}-0.148 * * \\
(0.052)\end{array}$ & $\begin{array}{l}-0.205^{* * * *} \\
(0.059)\end{array}$ \\
\hline Mountainous terrain (ln) & $\begin{array}{c}0.015 \\
(0.047)\end{array}$ & $\begin{array}{c}0.034 \\
(0.047)\end{array}$ & $\begin{array}{c}0.003 \\
(0.048)\end{array}$ \\
\hline Ethnic fractionalization & $\begin{array}{l}-0.389 \\
(0.343)\end{array}$ & $\begin{array}{l}-0.203 \\
(0.336)\end{array}$ & $\begin{array}{l}-0.439 \\
(0.358)\end{array}$ \\
\hline Rural population (per cent) & $\begin{array}{c}0.022 * * * \\
(0.006)\end{array}$ & $\begin{array}{c}0.024 * * * \\
(0.005)\end{array}$ & $\begin{array}{c}0.024 * * * \\
(0.006)\end{array}$ \\
\hline Conflicts & $\begin{array}{c}0.005 * * * \\
(0.001)\end{array}$ & $\begin{array}{c}0.002 \\
(0.003)\end{array}$ & $\begin{array}{l}0.005^{* *} \\
(0.001)\end{array}$ \\
\hline Oil production per capita & $\begin{array}{c}-0.119 * * \\
(0.043)\end{array}$ & $\begin{array}{l}-0.119 \dagger \\
(0.069)\end{array}$ & $\begin{array}{c}-0.090^{*} \\
(0.041)\end{array}$ \\
\hline Constant & $\begin{array}{c}1.968 \\
(1.377)\end{array}$ & $\begin{array}{c}1.411 \\
(1.271)\end{array}$ & $\begin{array}{l}2.481 \dagger \\
(1.345)\end{array}$ \\
\hline Observations & 119 & 114 & 147 \\
\hline
\end{tabular}

Robust standard errors in parentheses, $* * * \mathrm{p}<0.001 ; * * \mathrm{p}<0.01 ; * \mathrm{p}<0.05 ; \dagger \mathrm{p}<0.1$.

$\mathrm{DV}=$ dependent variable; GDP $=$ gross domestic product; $\mathrm{ln}=$ natural logarithm.

All independent variables are taken for the year 2002. Dependent variable is taken for the year 2003. 
We additionally check whether the differences in the means between the two groups, both in terms of democracy and corruption, are significant using a t-test. The results confirm that the differences in the means are significant. We perform a number of alternative tests to check if the results hold for other specifications used by Min (2015). The results are presented in Table 3. Model 1 excludes OECD countries to eliminate the possibility that the interaction effect is driven by the group of Western democracies. Model 2 presents the results for the sample of countries with gross national income (GNI) lower than 11905 per capita, classified as developing nations by the World Bank. GNI per capita is expressed in constant 2005 U.S. dollars and taken from the World Development Indicators (2014) through the QoG Dataset (Teorell et al., 2018). Model 3 uses a continuous measure of democracy - a combined Freedom House/Polity score suggested by Hadenius and Teorell (2005) - to calculate countries' democratic experience. The index is a calculated average of Freedom House and Polity IV democracy scores. For countries and years where data on Polity IV are missing, the index contains imputed values calculated by regressing Polity on the average Freedom House indicator. Hadenius and Teorell (2005) show that the average index performs better in terms of validity and reliability than each of the indices separately. The index ranges from 0 to 10 , where 0 stands for totalitarian regimes, while 10 corresponds to the most democratic polities. We code countries' democratic experience as a number of years in which a country received a score above 6.67 on Freedom House/Polity IV index, which is a threshold of democracy suggested by Hadenius and Teorell (2005). The indicator captures democratic history starting from 1972.

Figure 3: The relationship between democratic experience and the proportion of population living in unlit areas conditional on public sector corruption (Models 1-3 in Table 2).
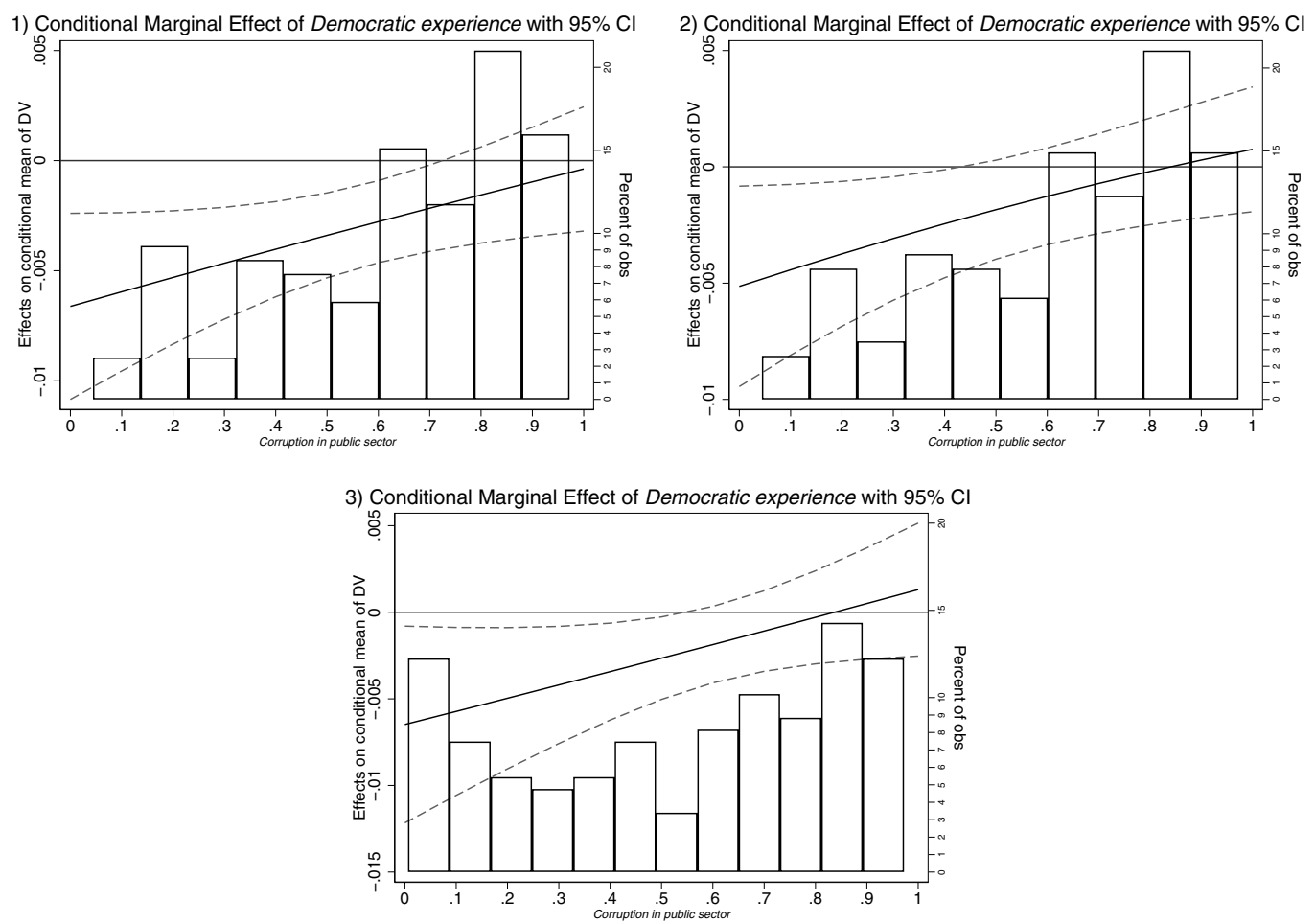

Note $: \mathrm{DV}=$ dependent variable $; \mathrm{CI}=$ confidence intervals 
The results are consistent across the models, showing that the conditional effect of democracy on corruption holds in all selected sub-samples. Figure 3 shows conditional marginal effect plots for each model and reveals a similar pattern to the one found in Figure 2: democratic experience plays a role in electrification rates only in countries where the level of corruption in public administration is low and where the state is capable of implementing such long-term projects as universal electrification. In countries with high corruption, longer experience with democracy does not seem to influence electricity provision.

In sum, holding several important factors constant, corruption does not seem to have an independent effect on the electricity provision. However, it does seem to moderate the effect of democratic experience - an effect well documented in the previous research. Longer democracy experience is associated with a lower share of people living in unlit areas, but only in countries, which have managed to curb corruption to at least some extent. In countries where corruption is high, longer democratic experience does not seem to help improve electrification rates.

\section{DISCUSSION AND CONCLUSIONS}

This paper has investigated the interdependent effects of democratic experience and corruption in the public administration on electricity provision. The aim has been to contribute to our understanding of how experience with a certain regime type and the quality of implementing institutions in the political system together affect the prerequisites for successful electrification, which is Sustainable Development Goal number seven under the United Nations' framework (United Nations, 2015b). According to the seventh SDG (United Nations, 2015b), provision of affordable, reliable, and sustainable energy initiated by countries' governments is crucial for people to develop economically and socially. Democracy has been identified as an important determinant of how successful countries and governments are in reaching this goal (Min, 2015). Taking as a point of departure the prominent work by Brian Min (2015), which investigates the association between democratic experience and the extent of electrification, this paper has suggested that we can get a more nuanced understanding of the role of democracy in public service provision by taking corruption into account. The paper argues that the extent to which democracies provide public services depends on the quality of public administration, which is responsible for the implementation of public policies. In contrast to most previous studies that discuss the disruptive effects of corruption on the democratic rule, this paper puts this theoretical claim about the conditional relationship to empirical test.

We build our empirical strategy to make sure that our results are comparable with the established findings in the existing literature. The first stage of our analysis replicates the results in Min's book (2015) and retrieves a similar result suggesting that longer experience with democratic rule is associated with higher levels of electrification. The second stage of our analysis directly tests our hypothesis, which posits that the effect of democracy on electricity provision depends on the level of corruption, and that the positive effect of democratic experience on electrification is weaker in contexts where corruption in public administration is widespread. The results from our tests lend support to the hypothesis. Democratic history seems to be associated with a lower share of population living in unlit areas only if a country has been able to reduce corruption to a certain level. In the context of widespread corruption, where public sector employees routinely embezzle state resources and/or grant favors for bribes, long experiences with democracy do not seem to have an effect on the provision of electricity to the population. However, once a certain level of control over corruption is in place, democracy does have the expected desirable effect. These findings complement the work by Min (2015) and add to our knowledge about the political determinants of public service 
provision. They emphasize that taking the implementation process into account enhances our understanding of the role that democratic institutions play in the delivery of public services.

\section{ACKNOWLEDGMENTS}

This project has received funding from the European Research Council (ERC) under the European Union's Horizon 2020 research and innovation program (grant agreement No 339571), and from the Centre for Collective Action Research (CeCAR) at the University of Gothenburg. The authors are grateful to the researchers at the Quality of Government Institute for many helpful comments and suggestions at the early stages of the paper.

\section{REFERENCES}

Abbott, Malcolm (2001). "Is the security of electricity supply a public good?" The Electricity Journal 14(7): 31-33. https:// doi.org/10.1016/S1040-6190(01)00224-X.

Acemoglu, Daron and James A. Robinson (2006). Economic origins of dictatorship and democracy: Cambridge University Press. https://doi.org/10.1017/CBO9780511510809.

Ahlbom Persson, Tove and Marina Povitkina (2017). "'Gimme Shelter': The Role of Democracy and Institutional Quality in Disaster Preparedness.” Political Research Quarterly 70(4): 833-847. https://doi.org/10.1177/1065912917716335.

Ahlborg, Helene, Frida Boräng, Sverker C. Jagers, and Patrik Söderholm (2015). "Provision of electricity to African households: The importance of democracy and institutional quality." Energy Policy 87: 125-135. https://doi.org/10.1016/j.enpol.2015.09.002.

Ahlborg, Helene and Linus Hammar (2014). "Drivers and barriers to rural electrification in Tanzania and MozambiqueGrid-extension, off-grid, and renewable energy technologies.” Renewable Energy 61: 117-124. https://doi.org/10.1016/j. renene.2012.09.057.

Baskaran, Thushyanthan, Brian Min, and Yogesh Uppal (2015). "Election cycles and electricity provision: Evidence from a quasi-experiment with Indian special elections." Journal of Public Economics 126: 64-73. https://doi.org/10.1016/j. jpubeco.2015.03.011.

Beekman, Gonne, Erwin Bulte, and Eleonora Nillesen (2014). "Corruption, investments and contributions to public goods: Experimental evidence from rural Liberia.” Journal of Public Economics 115: 37-47. https://doi.org/10.1016/j.jpubeco.2014.04.004.

Besley, Timothy, and Stephen Coate (1998). "Sources of inefficiency in a representative democracy: a dynamic analysis." American Economic Review 139-156.

Boräng, Frida, Sverker C. Jagers, and Marina Povitkina (2016). "Political determinants of electricity provision in small island developing states.” Energy Policy 98: 725-734. https://doi.org/10.1016/j.enpol.2016.04.040 .

Bratton, Michael, and Nicholas Van de Walle (1997). Democratic experiments in Africa: Regime transitions in comparative perspective. Cambridge University Press. https://doi.org/10.1017/CBO9781139174657.

Bratton, Michael, and Nicolas Van de Walle (1994). "Neopatrimonial regimes and political transitions in Africa." World politics 46(4): 453-489. https://doi.org/10.2307/2950715.

Brown, David S. and Ahmed Mushfiq Mobarak (2009). "The transforming power of democracy: regime type and the distribution of electricity." American Political Science Review 103(2): 193-213. https://doi.org/10.1017/S0003055409090200.

Bueno de Mesquita, Bruce (2003). The logic of political survival. Cambridge, Mass.; London: MIT Press. https://doi. org/10.7551/mitpress/4292.001.0001.

Chandra, Kanchan (2004). Why ethnic parties succeed: Patronage and ethnic head counts in India. Cambridge, UK: Cambridge University Press. https://doi.org/10.1017/9781108573481.

Cheibub, José Antonio, Jennifer Gandhi, and James Raymond Vreeland (2010). "Democracy and dictatorship revisited." Public Choice 143(1-2): 67-101. https://doi.org/10.1007/s11127-009-9491-2.

Chhibber, Pradeep, Sandeep Shastri, and Richard Sisson (2004). "Federal arrangements and the provision of public goods in India." Asian Survey 44(3): 339-352. https://doi.org/10.1525/as.2004.44.3.339.

Coppedge, Michael, John Gerring, Carl Henrik Knutsen, Staffan I. Lindberg, Svend-Erik Skaaning, Jan Teorell, David Altman, Michael Bernhard, Steven M. Fish, Agnes Cornell, Sirianne Dahlum, Haakon Gjerløw, Adam Glynn, Allen Hicken, Joshua Krusell, Anna Lührmann, Kyle Marquardt, Kelly McMann, Valeriya Mechkova, Jurai Medzihorsky, Moa Olin, Pa- 
mela Paxton, Daniel Pemstein, Josefine Pernes, Johannes von Römer, Brigitte Seim, Rachel Sigman, Jeffrey Staton, Natalia Stepanova, Aksel Sundström, Eitan Tzelgov, Yi-ting Wang, Tore Wig, Steven Wilson, and Daniel Ziblatt (2018a). "V-Dem [Country-Year/Country-Date] Dataset v8." Varieties of Democracy (V-Dem) Project.

Coppedge, Michael, John Gerring, Carl Henrik Knutsen, Staffan I. Lindberg, Svend-Erik Skaaning, Jan Teorell, David Altman, Michael Bernhard, Steven M. Fish, Agnes Cornell, Sirianne Dahlum, Haakon Gjerløw, Adam Glynn, Allen Hicken, Joshua Krusell, Anna Lührmann, Kyle Marquardt, Kelly McMann, Valeriya Mechkova, Jurai Medzihorsky, Moa Olin, Pamela Paxton, Daniel Pemstein, Josefine Pernes, Johannes von Römer, Brigitte Seim, Rachel Sigman, Jeffrey Staton, Natalia Stepanova, Aksel Sundström, Eitan Tzelgov, Yi-ting Wang, Tore Wig, Steven Wilson, and Daniel Ziblatt (2018b). "V-Dem Codebook v8." Varieties of Democracy (V-Dem) Project.

Dahlström, Carl and Victor Lapuente (2017). Organizing Leviathan: Politicians, Bureaucrats, and the Making of Good Government. Cambridge University Press. https://doi.org/10.1017/9781316822869.

Dahlström, Carl, Johannes Lindvall, and Bo Rothstein (2013). "Corruption, bureaucratic failure and social policy priorities." Political Studies 61(3): 523-542. https://doi.org/10.1111/j.1467-9248.2012.00998.x.

Dahlström, Carl, Marina Nistotskaya, and Maria Tyrberg (2018). "Outsourcing, bureaucratic personnel quality and citizen satisfaction with public services.” Public Administration 96(1): 218-233. https://doi.org/10.1111/padm.12387.

Diamond, Larry Jay (2007). “A Quater-Century of Promoting Democracy.” Journal of Democracy 18: 118-120.

Fearon, James D., and David D. Laitin (2003). "Ethnicity, insurgency, and civil war.” American political science review 97(1): 75-90. https://doi.org/10.1017/S0003055403000534.

Gandhi, Jennifer and Adam Przeworski (2006). "Cooperation, cooptation, and rebellion under dictatorships.” Economics \& Politics 18(1): 1-26. https://doi.org/10.1111/j.1468-0343.2006.00160.x.

Gerring, John, Strom C. Thacker, and Rodrigo Alfaro (2012). “Democracy and human development.” The Journal of Politics 74(1): 1-17. https://doi.org/10.1017/S0022381611001113.

Gleditsch, Kristian Skrede (2011). Expanded Trade and GDP Data.

Gormley, William T. and Steven J. Ball (2012). Bureaucracy and Democracy: Accountability and Performance Third ed: CQ Press.

Gupta, Sanjeev, Hamid Reza Davoodi, and Erwin Tiongson (2000). Corruption and the provision of health care and education services: International Monetary Fund.

Hadenius, Axel and Jan Teorell (2005). “Assessing Alternative Indices of Democracy.” C\&M Working Papers 6, IPSA, August 2005 .

Haggard, Stephan (1991). “Inflation and Stabilization.” In Politics and Policy Making in Developing Countries: Perspectives on the New Political Economy, edited by Gerald M. Meler, 233-49. San Francisco: ICS Press.

Hanson, Jonathan K. (2015). "Democracy and State Capacity: Complements or Substitutes?" Studies in Comparative International Development 50(3): 304-330. https://doi.org/10.1007/s12116-014-9173-z.

Hicken, Allen (2011). “Clientelism.” Annual Review of Political Science 14: 289-310. https://doi.org/10.1146/annurev. polisci.031908.220508.

Holmberg, Sören, Bo Rothstein, and Naghmeh Nasiritousi (2009). “Quality of Government: What You Get.” Annual Review of Political Science 12(1): 135-161. https://doi.org/10.1146/annurev-polisci-100608-104510.

Jones, Gary J. and Griffin Thompson (1996). "Renewable energy for African development." Solar Energy 58(1): $103-109$. https://doi.org/10.1016/0038-092X(96)00057-6.

Karekezi, Stephen and Lugard Majoro (2002). “Improving modern energy services for Africa's urban poor.” Energy Policy 30(11): 1015-1028. https://doi.org/10.1016/S0301-4215(02)00055-1.

Kaufmann, Daniel and Aart Kraay (2002). "Growth without governance.” World Bank Policy Research Working Paper (2928). https://doi.org/10.1353/eco.2002.0016.

Keefer, Philip (2007). "Clientelism, Credibility, and the Policy Choices of Young Democracies.” American Journal of Political Science 51(4): 804-821. https://doi.org/10.1111/j.1540-5907.2007.00282.x.

Kitschelt, Herbert (2000). "Linkages between citizens and politicians in democratic polities." Comparative political studies 33(6-7): 845-879. https://doi.org/10.1177/001041400003300607.

Knutsen, Carl Henrik (2013). “Democracy, State Capacity, and Economic Growth.” World Development 43: 1-18. https://doi. org/10.1016/j.worlddev.2012.10.014.

La Porta, Rafael, Florencio Lopez-de-Silanes, Andrei Shleifer, and Robert Vishny (1999). "The quality of government." Journal of Law, Economics, and organization 15(1): 222-279. https://doi.org/10.1093/jleo/15.1.222.

Lake, David A. and Matthew A. Baum (2001).’The invisible hand of democracy political control and the provision of public services." Comparative political studies 34(6): 587-621. https://doi.org/10.1177/0010414001034006001.

Lal, Sumir (2005). "Can good economics ever be good politics? Case study of the power sector in India." Economic and Political Weekly 649-656. https://doi.org/10.1596/978-0-8213-6680-6. 
Lewis, David E. (2007). “Testing Pendleton’s Premise: Do Political Appointees Make Worse Bureaucrats?” The Journal of Politics 69(4): 1073-1088. https://doi.org/10.1111/j.1468-2508.2007.00608.x.

Mauro, Paolo (1998). "Corruption and the composition of government expenditure." Journal of Public economics 69(2): 263-279. https://doi.org/10.1016/S0047-2727(98)00025-5.

McGuire, Martin C. and Mancur Olson (1996). "The economics of autocracy and majority rule: the invisible hand and the use of force." Journal of economic literature 34(1): 72-96.

Meltzer, Allan H. and Scott F. Richard (1981).”A rational theory of the size of government." The Journal of Political Economy 914-927. https://doi.org/10.1086/261013.

Min, Brian (2015). Power and the Vote: Elections and Electricity in the Developing World: Cambridge University Press. https://doi.org/10.1017/CBO9781316272121.

North, Douglass C. (1990). Institutions, institutional change, and economic performance, The Political economy of institutions and decisions. Cambridge; New York: Cambridge University Press. https://doi.org/10.1017/CBO9780511808678.

Nye, Joseph S. (1967). "Corruption and political development: A cost-benefit analysis." American political science review 61(2): 417-427. https://doi.org/10.2307/1953254.

Papke, L.E. and Jeffrey Wooldridge, M. (1996). "Econometric methods for fractional response variables with an application to 401(k) plan participation rates." Journal of Applied Economics 11(6): 619-632. https://doi.org/10.1002/(SICI)10991255(199611)11:6<619::AID-JAE418>3.0.CO;2-1

Povitkina, Marina (2018). "The limits of democracy in tackling climate change." Environmental politics 27(3): 411-432. https://doi.org/10.1080/09644016.2018.1444723 .

Povitkina, Marina, and Ketevan Bolkvadze (2019). "Fresh pipes with dirty water: How quality of government shapes the provision of public goods in democracies." European Journal of Political Research 58(4): 1191-1212. https://doi. org/10.1111/1475-6765.12330.

Ross, Michael (2006). “Is democracy good for the poor?” American Journal of Political Science 50(4): 860-874. https://doi. org/10.1111/j.1540-5907.2006.00220.x.

Ross, Michael and Paasha Mahdavi (2015). “Oil and gas data, 1932-2014.” Harvard Dataverse Network.

Rothstein, Bo (2011).The quality of government: corruption, social trust, and inequality in international perspective. Chicago: University of Chicago Press. https://doi.org/10.7208/chicago/9780226729589.001.0001.

Rothstein, Bo, Marcus Samanni, and Jan Teorell (2012). "Explaining the welfare state: power resources vs. the Quality of Government.” European Political Science Review 4(1): 1-28. https://doi.org/10.1017/S1755773911000051.

Samuelson, Paul A. (1954). "The Pure Theory of Public Expenditure.” The Review of Economics and Statistics 36(4): 387389. https://doi.org/10.2307/1925895.

Sen, Amartya (1999). Development as freedom. New York: Oxford University Press.

Teorell, Jan, Stefan Dahlberg, Sören Holmberg, Bo Rothstein, Natalia Alvarado, and Richard Svensson (2018). The Quality of Government Standard Dataset. The Quality of Government Institute: University of Gothenburg.

Themnér, Lotta and Peter Wallensteen (2013). “Armed Conflicts, 1946-2012.” Journal of Peace Research 50(4): 509-521. https://doi.org/10.1177/0022343313494396.

United Nations (2015a). "Sustainable Development Goals.” accessed 20 August. http://www.un.org/sustainabledevelopment/ sustainable-development-goals/.

United Nations (2015b). "Sustainable Development Goals 7.” accessed 10 November. http://www.un.org/sustainabledevelopment/energy/.

World Bank (2014). World Development Indicators, the World Bank. In World Bank Publications.

Wooldridge, Jeffrey M. (2002). Econometric analysis of cross section and panel data. Cambridge, MA: Massachusetts Institute of Technology.

Zomers, Adriaan (2003). "The challenge of rural electrification.” Energy for sustainable development 7(1): 69-76. https://doi. org/10.1016/S0973-0826(08)60349-X. 


\section{APPENDIX A: SUMMARY STATISTICS AND CORRELATIONS}

Table A.1: Summary statistics

\begin{tabular}{|c|c|c|c|c|c|}
\hline Variable & Obs & Mean & Std. Dev. & Min & Max \\
\hline Proportion of population in unlit areas, 2003 & 148 & 0.22 & 0.22 & 0 & 0.88 \\
\hline Democracy experience (Cheibub), 1946-2002 & 191 & 17.31 & 19.52 & 0 & 58 \\
\hline Democracy experience (FH/PolityIV), 1972-2002 & 249 & 8.78 & 10.94 & 0 & 30 \\
\hline Public Sector Corruption, 2002 & 171 & 0.51 & 0.31 & 0 & 0.97 \\
\hline GDP per capita $(\ln ), 2002$ & 192 & 8.50 & 1.30 & 5.29 & 11.24 \\
\hline Latitude & 194 & 25.33 & 17.09 & 0 & 65 \\
\hline Population Density (ln), 2002 & 191 & 4.16 & 1.44 & 0.45 & 9.7 \\
\hline Mountainous terrain $(\ln )$ & 168 & 2.14 & 1.42 & 0 & 4.56 \\
\hline Ethnic Fractionalization, 2002 & 165 & 0.47 & 0.26 & 0 & 1 \\
\hline Rural population, 2002 & 191 & 46.55 & 23.74 & 0 & 91.32 \\
\hline Conflicts, 1946-2002 & 249 & 5.44 & 19.21 & 0 & 235 \\
\hline Oil production per capita, 2002 & 171 & 1.94 & 7.09 & 0 & 54.15 \\
\hline
\end{tabular}

Note: GDP = gross domestic product; $\ln =$ natural logarithm; FH = Freedom House; Obs = obervations; Std. Dev. $=$ standard deviation; Min = minimum; $\operatorname{Max}=$ maximum .

Table A.2. Correlation between variables

\begin{tabular}{|c|c|c|c|c|c|c|c|c|c|c|c|}
\hline & $\begin{array}{c}\% \text { of pop } \\
\text { unlit }\end{array}$ & $\begin{array}{l}\text { Dem. } \\
\text { exp. }\end{array}$ & Corr & $\begin{array}{l}\text { GDP/ } \\
\text { capita }\end{array}$ & Latitude & $\begin{array}{l}\text { Pop. } \\
\text { dens. }\end{array}$ & $\begin{array}{l}\text { Mount. } \\
\text { Ter. }\end{array}$ & $\begin{array}{c}\text { Ethnic } \\
\text { frac }\end{array}$ & $\begin{array}{c}\text { Rural } \\
\text { pop }\end{array}$ & Conflicts & $\begin{array}{c}\text { Oil prod/ } \\
\text { capita }\end{array}$ \\
\hline$\%$ of pop unlit & 1.000 & & & & & & & & & & \\
\hline Dem. experience & -0.453 & 1.000 & & & & & & & & & \\
\hline $\begin{array}{l}\text { Public sector } \\
\text { corruption }\end{array}$ & 0.486 & -0.629 & 1.000 & & & & & & & & \\
\hline GDP/capita(ln) & -0.775 & 0.586 & -0.723 & 1.000 & & & & & & & \\
\hline Latitude & -0.581 & 0.288 & -0.456 & 0.658 & 1.000 & & & & & & \\
\hline Pop. Dens.(ln) & -0.089 & 0.174 & -0.136 & 0.068 & 0.064 & 1.000 & & & & & \\
\hline Mount.Ter.(ln) & 0.081 & 0.033 & 0.124 & -0.070 & -0.037 & 0.044 & 1.000 & & & & \\
\hline Ethnic frac. & 0.411 & -0.313 & 0.337 & -0.484 & -0.517 & -0.274 & -0.048 & 1.000 & & & \\
\hline Rural pop. & 0.755 & -0.474 & 0.527 & -0.770 & -0.502 & 0.061 & 0.133 & 0.352 & 1.000 & & \\
\hline Conflicts & 0.182 & 0.069 & 0.111 & -0.116 & -0.141 & 0.140 & 0.154 & 0.120 & 0.155 & 1.000 & \\
\hline Oil prod/capita & -0.214 & -0.042 & -0.107 & 0.284 & 0.054 & -0.164 & -0.122 & 0.041 & -0.291 & -0.072 & 1.000 \\
\hline
\end{tabular}

Note: $\%$ of pop unlit = percentage of population living in unlit areas; Dem. = democratic; Exp. $=$ experience; GDP $=$ gross domestic product; $\ln =$ natural logarithm; pop. = population; dens. $=$ density; Mount.Ter. $=$ Mountainous terrain; frac. $=$ fractionalization; prod. $=$ production; corr $=$ public sector corruption

\section{APPENDIX B: COUNTRIES INCLUDED IN THE ANALYSIS}

$\begin{array}{lll}\text { Afghanistan } & \text { Bulgaria } & \text { Congo, Democratic Republic } \\ \text { Albania } & \text { Myanmar } & \text { Costa Rica } \\ \text { Algeria } & \text { Burundi } & \text { Croatia } \\ \text { Angola } & \text { Belarus } & \text { Cuba } \\ \text { Azerbaijan } & \text { Cambodia } & \text { Czech Republic } \\ \text { Argentina } & \text { Cameroon } & \text { Benin } \\ \text { Australia } & \text { Canada } & \text { Denmark } \\ \text { Austria } & \text { Central African Republic } & \text { Dominican Republic } \\ \text { Bangladesh } & \text { Sri Lanka } & \text { Ecuador } \\ \text { Armenia } & \text { Chad } & \text { El Salvador } \\ \text { Belgium } & \text { Chile } & \text { Ethiopia } \\ \text { Bolivia } & \text { China } & \text { Eritrea } \\ \text { Bosnia and Herzegovina } & \text { Taiwan } & \text { Estonia } \\ \text { Botswana } & \text { Colombia } & \text { Finland } \\ \text { Brazil } & \text { Congo } & \text { France }\end{array}$




\begin{tabular}{|c|c|c|}
\hline Gabon & Madagascar & Vietnam \\
\hline Georgia & Malawi & Slovenia \\
\hline Gambia & Malaysia & Somalia \\
\hline Germany & Mali & South Africa \\
\hline Ghana & Mauritania & Zimbabwe \\
\hline Greece & Mexico & Spain \\
\hline Guatemala & Mongolia & Sudan \\
\hline Guinea & Moldova & Swaziland \\
\hline Haiti & Morocco & Sweden \\
\hline Honduras & Mozambique & Switzerland \\
\hline Hungary & Namibia & Syria \\
\hline India & Nepal & Tajikistan \\
\hline Indonesia & Netherlands & Thailand \\
\hline Iran & New Zealand & Togo \\
\hline Iraq & Nicaragua & Trinidad and Tobago \\
\hline Ireland & Niger & Tunisia \\
\hline Israel & Nigeria & Turkey \\
\hline Italy & Norway & Turkmenistan \\
\hline Cote d'Ivoire & Oman & Uganda \\
\hline Jamaica & Pakistan & Ukraine \\
\hline Japan & Panama & Macedonia \\
\hline Kazakhstan & Papua New Guinea & Egypt \\
\hline Jordan & Paraguay & United Kingdom \\
\hline Kenya & Peru & Tanzania \\
\hline Korea, North & Philippines & United States \\
\hline Korea, South & Poland & Burkina Faso \\
\hline Kuwait & Portugal & United Arab Emirates \\
\hline Kyrgyzstan & Guinea-Bissau & Uruguay \\
\hline Laos & Romania & Uzbekistan \\
\hline Lebanon & Russia & Venezuela \\
\hline Lesotho & Rwanda & Yemen \\
\hline Latvia & Saudi Arabia & Zambia \\
\hline Liberia & Senegal & Serbia and Montenegro \\
\hline Libya & Sierra Leone & \\
\hline Lithuania & Slovakia & \\
\hline
\end{tabular}

*Serbia and Montenegro is only included in replication models 1 and 2 in Table 1 due to data availability 

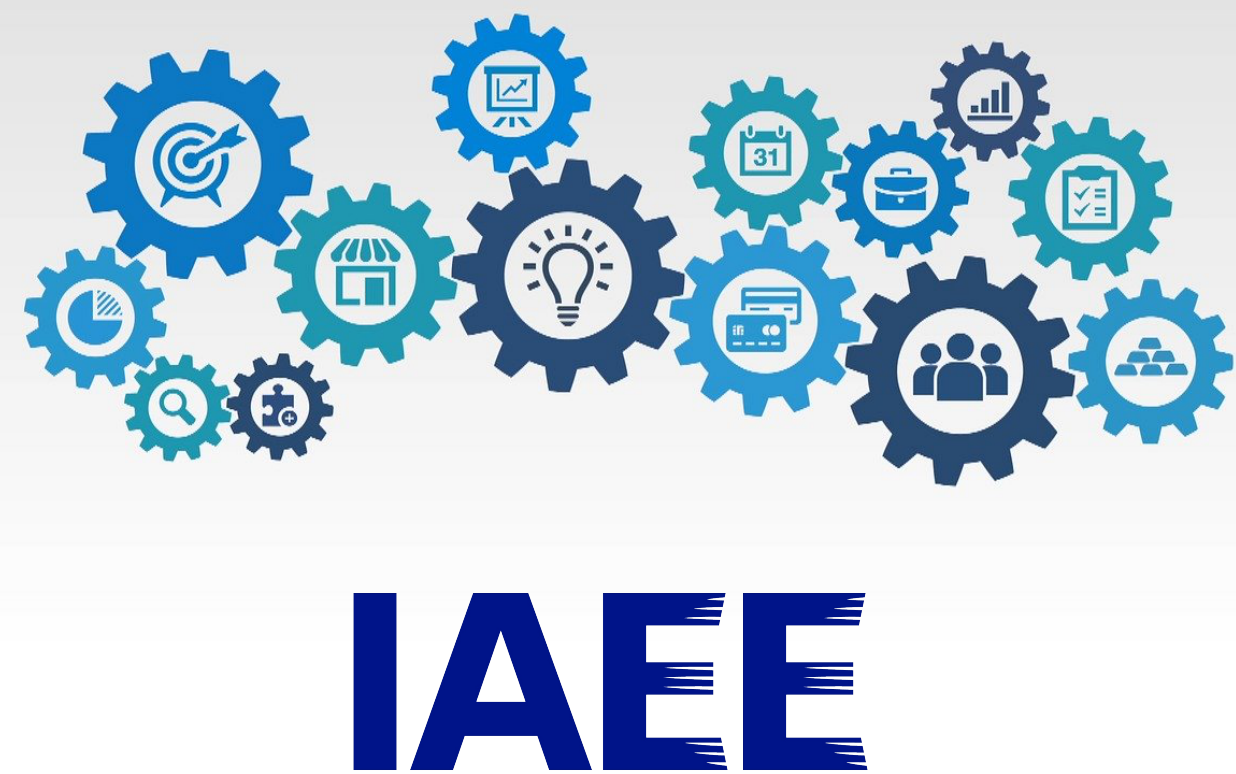

International Association for

\section{ENERGY ECONOMICS}

Membership in the International Association for Energy Economics is open to anyone worldwide who has an interest in the fields of energy or energy economics. Our membership consists of those working in both the public and private sectors including government, academic and commercial. Our current member base consists of $3900+$ members in over 110 nations, with 28 nations having local affiliate organization.

We are an independent, non-profit, global membership organization for business, government, academic and other professionals concerned with energy and related issues in the international community. We advance the knowledge, understanding and application of economics across all aspects of energy and foster communication amongst energy concerned professionals.

We are proud of our membership benefit offerings, which include access to a rich library of energy economics related publications and proceedings as well as a robust line-up of webinars, podcasts and conferences. Learn more about the benefits of membership at:

https://www.iaee.org/en/membership/benefits.aspx

In addition to traditional membership, we offer student and institutional memberships. 